\title{
Editorial
}

\section{Sustainable Tourism: Trends, Challenges and Concerns}

https://doi.org/10.2478/ejthr-2019-0013

Tourism is a fundamental part of society, and is therefore embedded within contemporary capitalism and social values (Bramwell \& Lane, 2014). Recently, tourism research following the general trend across social sciences has been affected by a "critical turn" (Bramwell \& Lane, 2014; Tribe, 2008, 2010). The focus is on challenging established thinking and questioning the concepts of power and product (Tribe, 2006). Also, the critical turn aims to counterbalance the almost "tyrannical role of economics", which only considers tourism as an economic activity (Tribe, 2006, p. 366). In fact, the established mindset underpinning tourism planning, development and research is increasingly under attack from many quarters on the grounds that "business as usual" seems impossible to reconcile with "sustainability". (Dwyer, 2018).

The concept of "sustainability" began with the document Our Common Future (WCED, 1987) in which sustainable development was defined as "satisfying the needs of the present generation without compromising the ability of future generations to meet their needs" (WCED, 1987, ch. 2, sec. 1, para. 1). By now, we can all understand the contradiction and ambiguity of joining the terms, since the term "sustainable" implies some form of limits while the term "development" emphasises human use to meet human needs (Higgins-Desbiolles, 2018). Due to this ambiguity, the concept of sustainability has been very malleable in the interests of those benefiting from a status quo strategy (Higgins-Desbiolles, 2018).

Nonetheless, and according to OECD (2018), sustained development of the tourism sector will depend on the ability to adapt to emerging economic, social, political, environmental and technological trends. However, the use of tourism's potential as an engine for sustainable and inclusive growth needs adequate policies, integrated strategies, inter-ministerial structures and mechanisms that involve the private sector and other stakeholders in tourism governance. In fact, over the past few decades, we have witnessed a growing recognition of the important role that the development, management and promotion of local destinations play, supported by regional or local structures and funding, and the preparation and execution of destination management plans.

This special issue aims to capture new ways of thinking about tourism sustainability in national, regional and local contexts and how it affects other areas of society. This will help to evaluate different potential developments and make suggestions about future creative needs in the tourism sector.

By taking an applied approach to tourism sustainability, this special journal issue focuses on understanding new trends and topics that need further inquiry. We hope that we have contributed to a better understanding of how tourism sustainability is conceptualised and how tourism managers and stakeholders can operationalise tourism sustainability under a global-local perspective. As such, paper contributions to this special journal issue attempt to bridge the global and the local through sustainable tourism by focusing on new or understudied phenomena, through a set of different contributions and approaches.

In the first contribution, Dolores Gallardo-Vázquez, Oscar Ernesto Hernández-Ponce and Luis Enrique Valdez Juárez present an analysis of the success factors of sustainable tourism in the southern region of the State of Sonora, Mexico, supported by multiple case studies of tourist places in Guaymas, Isla Huivulai and Alamos. Based on a non-experimental qualitative approach, the authors aimed to provide a framework for the development of an empirical database. The authors demonstrate that the most relevant factors considered for a sustainable tourism project to be successful in the research areas are natural and cultural beauties, accessibility to the market and the business profile. On the other hand, the factors of secondary importance for the success of a sustainable tourism project appear to be safety, accessibility to the place and protection of the environment. The paper provides useful insights for the various stakeholders involved, namely entrepreneurs, managers and government.

Sami El Geneidy and Stefan Baumeister conducted a detailed analysis of volunteer tourists from an Indian non-governmental organisation. The authors introduce an original focus on the impact on global greenhouse emissions by international volunteer tourists, by showing that 
while the carbon footprint of voluntourists during their stay is comparable with that of locals, their travel options, namely flights, significantly increase the carbon footprint of voluntourism, which needs to be taken into account together with the volunteers' length of stay.

Helmuth Yesid Arias Gómez and Gabriela Antošová apply an innovative cartographic and spatial approach and tools to explore the natural context and the geographic conditions of Bahía Solano in Colombia for developing eco-tourism and for designing sectorial plans. Their main objective is to offer basic visual rendering as a resource for appreciating the natural environment in which the tourist activity evolves. Their study demonstrates that planning and engaging various levels of governance could avoid threats to the environmental and social equilibrium of Bahía Solano and neighbouring regions.

The three papers focusing on human resources within the tourism and hospitality industry present equally relevant even though different perspectives on the crucial importance of training human resources for the tourism profession. Vânia Costa, Andreia Moura, Maria do Rosário Mira, António Cerdeiras, Inês Pinto da Cruz, José Filipe Pereira, Maria Isabel Martins, Oscarina Conceição, Abílio Vilaça, Bruno Pinheiro, Cláudia Almeida and Paulo Carrança present the HCTourism project which aims to depict the skills needed in the tourism industry by studying the active companies that belong to its various economic subsectors. By applying a mixed method approach and by collecting primary and secondary data, the authors compiled a list of 150 skills and applied an online survey to national tourist entrepreneurs in order to develop the ideal profile of the tourism professional. The authors believe the results of their study will contribute to better employment strategies and more qualified workers in the tourism sector, and consequently to an increase in quality of Portugal as a tourism destination.

Next, Cláudia Viegas and Anna Lins present an empirical study with students attending a Cookery and Food Production course at a higher education institution that reinforces the importance of training. The authors highlight how becoming aware of sustainable and balanced meals by reformulating the proportions of food, by focusing on vegetables and by decreasing the quantity of products of animal origin has strong implications on sustainability. Since food is very relevant for tourism, they emphasise the importance of training the food professionals to design and produce sustainable and balanced meals. Finally, Helena Roque and Madalena Ramos highlight the importance of human resources management practices and policies and how a cultural training programme, which according to the authors appears to have never been implemented, for professionals of the hospitality sector based on understanding and respect for cultural values and cultural differences may facilitate interaction between guests and professionals.

\section{References}

[1] Bramwell, B. \& Lane, B. (2014). The "critical turn” and its implications for sustainable tourism research, Journal of Sustainable Tourism, 22 (1), 1-8. DOI: 10.1080/09669582.2013.855223

[2] Brooker, E., \& Joppe, M. (2014). Developing a tourism innovation typology: Leveraging liminal insights. Journal of Travel Research, 53(4), 500-508. DOI: 10.1177/0047287513497839

[3] Dwyer, L. (2018) Saluting while the ship sinks: the necessity for tourism paradigm change, Journal of Sustainable Tourism, 26 (1), 29-48. DOI: 10.1080/09669582.2017.1308372

[4] Gretzel, U., Sigala, M., Xiang, Z. \& Koo, Ch. (2015) Smart tourism: foundations and developments, Electronic Markets, 25(3), 179-188. DOI : 10.1007/s12525-015-0196-8

[5] Higgins-Desbiolles, F. (2018). Sustainable tourism: Sustaining tourism or something more? Tourism Management Perspectives, 25, 157-160. https://doi.org/10.1016/j. tmp.2017.11.017

[6] Moscardo, G. (2008). Sustainable tourism innovation: Challenging basic assumptions. Tourism and Hospitality Research, 8(1), 4-13. https://doi.org/10.1057/thr.2008.7

[7] Rodríguez, I., Williams, A. M., \& Hall, C. M. (2014). Tourism innovation policy: Implementation and outcomes. Annals of Tourism Research, 49(1), 76-93.

[8] OECD (2018). OECD Tourism Trends and Policies Highlights 2018. Available at https://www.oecd.org/cfe/ tourism/2018-Tourism-Trends-Policies-Highlights-ENG.pdf.

[9] Tribe, J. (2006). The truth about tourism. Annals of Tourism Research, 33(2), 360-381. DOI: 10.1016/j.anals.2005.11.001

[10] Tribe, J. (2008) Tourism: A Critical Business, Journal of Travel Research, 46, 245-255. DOI: https://doi. org/10.1177/0047287507304051

[11] Tribe, J. (2010). Tribes, territories and networks in the tourism academy. Annals of Tourism Research, 37(1), 7-33. DOI: 10.1016/j.annals.2009.05.001

[12] Tsiotsou, R., \& Ratten, V. (2010). Future research directions in tourism marketing. Marketing Intelligence \& Planning, 28(4), 533-544. https://doi.org/10.1108/02634501011053702

Teresa Costa

Filipa Perdigão Ribeiro 